\title{
Major threats of pollution and climate change to global coastal ecosystems and enhanced management for sustainability
}

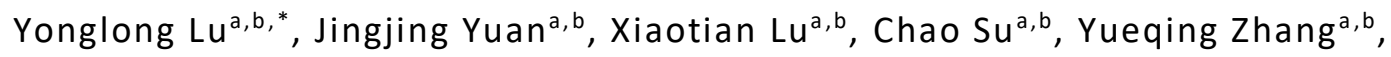

Chenchen Wang ${ }^{\mathrm{a}, \mathrm{b}}$, Xianghui Cao ${ }^{\mathrm{a}, \mathrm{b}}$, Qifeng $\mathrm{Li}^{\mathrm{a}, \mathrm{b}}$, Jilan $\mathrm{Su}^{\mathrm{c}}$, Venugopalan Ittekkot ${ }^{\mathrm{d}}$, Richard Angus Garbutt ${ }^{\mathrm{e}}$, Simon Bush ${ }^{\mathrm{f}}$, Stephen Fletcher ${ }^{\mathrm{g}, \mathrm{h}}$, Tonny Wagey', Anatolii Kachur ${ }^{j}$, Neville Sweijd ${ }^{k}$

a State Key Laboratory of Urban and Regional Ecology, Research Center for EcoEnvironmental Sciences, Chinese Academy of Sciences, Beijing, 100085, China

${ }^{b}$ University of Chinese Academy of Sciences, Beijing, 100049, China

c Second Institute of Oceanography, State Oceanic Administration, Hangzhou, 310012, China

d University of Bremen, 28359, Bremen, Germany

e Centre for Ecology and Hydrology, Gwynedd, LL57 2UW, UK

${ }^{f}$ Environmental Policy Group, Wageningen University, Wageningen, 6706 KN, The Netherlands

${ }^{g}$ UNEP World Conservation Monitoring Centre, Cambridge, CB3 ODL, UK

${ }^{h}$ Centre for Marine Conservation Policy Research, Plymouth University, Plymouth Devon, PL4 8AA, UK

' Centre for Coastal and Marine Resources Study, Bogor Agricultural University, Bogor, 16680, West Java, Indonesia

j Pacific Institute of Geography, Far East Branch, Russian Academy of Sciences, Vladivostok, 690041, Russia

${ }^{k}$ Council for Scientific and Industrial Research (CSIR), Pretoria, 0001, South Africa

This is the accepted manuscript of a paper published in Environmental Pollution. The final version may be accessed at https://doi.org/10.1016/j.envpol.2018.04.016.

\section{Abstract}

Coastal zone is of great importance in the provision of various valuable ecosystem services. However, it is also sensitive and vulnerable to environmental changes due to high human populations and interactions between the land and ocean. Major threats of pollution from over enrichment of nutrients, increasing metals and persistent organic pollutants (POPs), and climate change have led to severe ecological degradation in the coastal zone, while few studies 
have focused on the combined impacts of pollution and climate change on the coastal ecosystems at the global level. A global overview of nutrients, metals, POPs, and major environmental changes due to climate change and their impacts on coastal ecosystems was carried out in this study. Coasts of the Eastern Atlantic and Western Pacific were hotspots of concentrations of several pollutants, and mostly affected by warming climate. These hotspots shared the same features of large populations, heavy industry and (semi-) closed sea. Estimation of coastal ocean capital, integrated management of land-ocean interaction in the coastal zone, enhancement of integrated global observation system, and coastal ecosystembased management can play effective roles in promoting sustainable management of coastal marine ecosystems. Enhanced management from the perspective of mitigating pollution and climate change was proposed.

\section{Introduction}

Coastal zone is the interface between the land and sea, and represents one of the most important areas of the world oceans from a human perspective. Coastal marine ecosystems, which include estuaries, sea grass beds, salt marshes, tidal flats, mangroves, coral reefs and shelves, provide various beneficial services such as nutrient cycling, detoxification of pollutants, food production, raw materials and habitats, regulation of storm-induced disturbances, as well as recreational and entertainment activities (Costanza et al., 1997). Coastal and marine ecosystems provide about $2 \times 10^{10} \mathrm{~kg}$ of demersal fish and $8 \times 10^{9} \mathrm{~kg}$ of pelagic fish, which occupied 28\% of the global fish production in 2013 (FAO, 2013; Christensen et al., 2014). Coral reefs are estimated to be habitats for 830,000 species globally (Fisher et al., 2015). Salt marshes, mangroves and seagrasses store more carbon than the whole terrestrial ecosystem.

As the site of land and ocean interactions, coastal zone also acts as buffer zone between land and ocean. It protects uplands from storms and flooding and serves as filters removing pollutants and other land-derived materials before entering the ocean (Ferreira et al., 2017). Because of the enormous value provided, coastal zone is among the most densely populated regions of the world. Dense population and frequent exchange of material and energy in the coastal zone will in turn make it particularly sensitive and vulnerable to both natural and anthropogenic changes. Thus, landbased human activities, climate change and extreme events have led to severe environmental degradation in the coastal zone. They continue to pose an increasing threat to the coastal ecosystems. Major coastal marine ecosystem challenges are present worldwide, such as coral reef degradation, coastal eutrophication, coastal hypoxic, reclamation of coastal wetland, increasing heavy metals and emerging pollutants due to coastal exploitation (Halpern et al., 2008; Doney, 2010; Hoegh-Guldberg and Bruno, 2010; Jennerjahn, 2012; Statham, 2012; Halpern et al., 2015).

In order to "conserve and sustainably use the oceans, seas and marine resources" as stipulated by one of the United Nations Sustainable Development Goals since 2015 (ICSU and ISSC, 2015), a better understanding of the status quo and major threats to the coastal marine ecosystem including the impacts of land-based human activities and climate change is needed at several levels. Most studies addressing these issues have focused on nutrients or traditional pollutants on a regional or national scale. However, a global overview of major pollution issues caused by 
excess nutrients, metals and persistent organic pollutants, and major challenges due to climate change (Fig. 1) has not been conducted but is important to achieve the sustainable management of coastal zone.

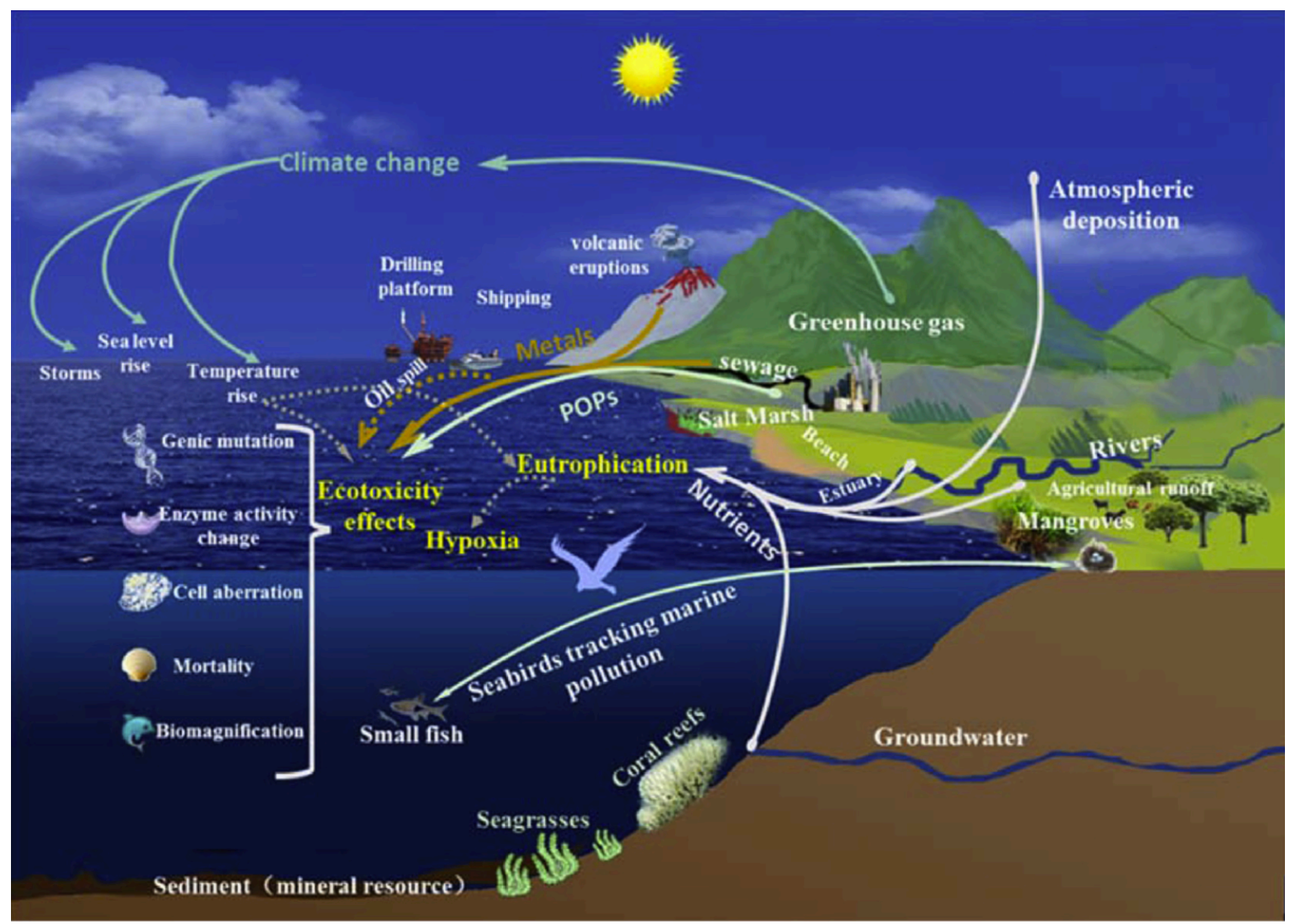

Fig 1. Conceptual map of major challenges in the coastal zone.

\section{Major problems and challenges in the coastal zone}

\subsection{Over enrichment of nutrients}

\subsubsection{Excess nutrient input and spatial distribution}

Eutrophication caused by excessive land-based nutrient inputs has affected many areas in the coastal zone. Based on the latest global coastal data of dissolved inorganic nitrogen (DIN) and dissolved inorganic phosphorus (DIP) concentrations available from literature (Table S1), East Asia and Western Europe are identified as hotspots of nutrient pollution while it is less severe in eastern North America (Fig. 2). In China, nutrients pollution in coastline mainly concentrates on Liaodong Bay, Bohai Bay, Yangtze Estuary, Hangzhou Bay and Pearl River Estuary (Liu et al., 2011; Wang et al., 2012; Strokal et al., 2014; Zhang, 2016). Nutrients over-enrichment also poses a serious threat to many coastal bays such as the Gulf of Mexico, North Sea and the Baltic 
Sea (Carstensen et al., 2014; O'Higgins and Gilbert, 2014; Rabotyagov et al., 2014; de Mutsert et al., 2016). The highest concentrations of DIN and DIP in the coastal surface water are $260 \mathrm{mM}$ at Hangzhou Bay in China and $5 \mathrm{mM}$ at Helgoland in Germany, respectively (Wiltshire et al., 2015; Zhang et al., 2015). Coasts along China, Western Europe and eastern North America have been seriously influenced by red tides and other ecological catastrophic events associated with eutrophication (Selman et al., 2008; Erisman et al., 2013). There is still paucity of coastal water quality data from Africa, Latin America and the Caribbean (Selman et al., 2008).

\subsubsection{Sources and drivers of nutrients}

Overall, agricultural runoff is the largest source of nitrogen pollution to many coastal ecosystems (Duce et al., 2008; Howarth, 2008; Hale et al., 2015). In addition, deforestation, human waste and aquaculture waste have also driven nutrient transported into coastal ecosystems (Hale et al., 2015; Lapointe et al., 2015). Atmospheric deposition and groundwater transportation are of growing importance, together accounting for $20 \%-50 \%$ of total exogenous loading among accelerating nitrogen inputs (Paerl et al., 2002; Troost et al., 2014; Xing et al., 2017). Regionally, they may be the largest single source of nitrogen pollution (Rodellas et al., 2015; Yadav et al., 2016; Pruell et al., 2017). Climate change and land use change may accelerate nutrient flux and coastal eutrophication (Brookes and Carey, 2011; Wells et al., 2015).

\subsection{Increasing metal concentration in coastal ecosystems}

\subsubsection{Global distribution of metal contamination in coastal sediments}

Concentrations of major metals in coastal sediments, including zinc ( $\mathrm{Zn})$, copper (Cu), chromium $(\mathrm{Cr})$, lead $(\mathrm{Pb})$, nickel $(\mathrm{Ni})$, arsenic $(\mathrm{As})$, mercury $(\mathrm{Hg})$, and cadmium $(\mathrm{Cd})$, are notable from the published literature. Most studies focus in Europe and Asia, with fewer concerning America, Africa, Australia or the Polar Regions. Concentration of $\mathrm{Zn}$ is relatively high in most regions while $\mathrm{Hg}$ is relatively low. Metal concentrations in North America and the Arctic are very low (Fig. 2).

Since metals vary in their ecotoxicities to the organisms, metal with the highest concentration does not necessarily pose the highest ecological risk (Su et al., 2017). According to the threshold effect level (TEL, below which adverse effects are not expected to occur) of Sediment Quality Guidelines (SQG) of US EPA, Cu, $\mathrm{Cr}$ and Ni show the most serious pollution. The highest concentrations and corresponding hotspots for each metal are listed in Table 1. The Egyptian Mediterranean coast seems to be the most seriously polluted region as a result of accumulation of several metals which is contributed by both the point sources like industry and non-point sources like sewage, irrigation and urban runoff (El-Sorogy et al., 2016). 
Table 1. Potential sources and hotspots for each metal.

\begin{tabular}{|c|c|c|c|c|c|}
\hline Metal & Sources & References & $\begin{array}{l}\text { The highest } \\
\text { concentration } \\
(\mathrm{mg} / \mathrm{kg})\end{array}$ & $\begin{array}{l}\text { Corresponding } \\
\text { sampling location }\end{array}$ & References \\
\hline $\mathrm{Cu}$ & $\begin{array}{l}\text { Acid mine, mine, coke, ore, paints } \\
\text { manufacturing, steel industry, } \\
\text { antifouling paints, steel industry, } \\
\text { industrial/domestic sewage, } \\
\text { copper-containing wood, oil spill }\end{array}$ & $\begin{array}{l}\text { (Osher et al., 2006; Nieto et } \\
\text { al., 2007; Moreno et al., 2011; } \\
\text { Popadic et al., 2013; Brady et } \\
\text { al., 2014) }\end{array}$ & 167.50 & $\begin{array}{l}\text { Guanabara Bay in } \\
\text { Brazil }\end{array}$ & $\begin{array}{l}\text { (Alaoui } \\
\text { et al., 2010) }\end{array}$ \\
\hline $\mathrm{Zn}$ & $\begin{array}{l}\text { Acid mine, mine, coke, ore, paints } \\
\text { manufacturing, steel industry, } \\
\text { industrial/domestic sewage, } \\
\text { antifouling paints, oil spill }\end{array}$ & $\begin{array}{l}\text { (Osher et al., 2006; Nieto et } \\
\text { al., 2007; Moreno et al., 2011; } \\
\text { Popadic et al., 2013; Brady et } \\
\text { al., 2014) }\end{array}$ & 1005.00 & $\begin{array}{l}\text { Moulay Bousselham } \\
\text { in Morocco }\end{array}$ & $\begin{array}{l}\text { (Borges } \\
\text { et al., 2014) }\end{array}$ \\
\hline $\mathrm{Pb}$ & $\begin{array}{l}\text { Metal refineries/production, coal } \\
\text { burning, metal refineries/ } \\
\text { production, cement production, } \\
\text { shipbuilding companies, natural } \\
\text { weathering, oil spill }\end{array}$ & $\begin{array}{l}\text { (Moreno et al., 2011; Popadic } \\
\text { et al., 2013; Chae et al., 2014) }\end{array}$ & 384.68 & $\begin{array}{l}\text { Egyptian } \\
\text { Mediterranean coast }\end{array}$ & $\begin{array}{l}\text { (El-Sorogy et al., } \\
2016)\end{array}$ \\
\hline $\mathrm{Cd}$ & $\begin{array}{l}\text { Acid mine, mine, coke, ore, } \\
\text { lithogenic, phosphate fertilizers }\end{array}$ & $\begin{array}{l}\text { (Osher et al., 2006; Nieto et } \\
\text { al., 2007; Dou et al., 2013; } \\
\text { Brady et al., 2014) }\end{array}$ & 28.88 & $\begin{array}{l}\text { Egyptian } \\
\text { Mediterranean coast }\end{array}$ & $\begin{array}{l}\text { (El-Sorogy et al., } \\
2016 \text { ) }\end{array}$ \\
\hline $\mathrm{Cr}$ & $\begin{array}{l}\text { Paints manufacturing, oil } \\
\text { combustion, geogenic source, } \\
\text { shipping (combustion of oils), } \\
\text { antifouling agents, oil spill } \\
\end{array}$ & $\begin{array}{l}\text { (Osher et al., 2006; Moreno et } \\
\text { al., 2011; Popadic et al., 2013; } \\
\text { Brady et al., 2014; Keshavarzi } \\
\text { et al., 2015) }\end{array}$ & 347.00 & $\begin{array}{l}\text { Dhamara Estuary in } \\
\text { India }\end{array}$ & $\begin{array}{l}\text { (Satapathy and } \\
\text { Panda, 2015) }\end{array}$ \\
\hline $\mathrm{Ni}$ & Oil combustion, geogenic source & $\begin{array}{l}\text { (Brady et al., 2014; Keshavarzi } \\
\text { et al., 2015) }\end{array}$ & 480.86 & $\begin{array}{l}\text { Egyptian } \\
\text { Mediterranean coast }\end{array}$ & $\begin{array}{l}\text { (El-Sorogy et al., } \\
\text { 2016) }\end{array}$ \\
\hline As & $\begin{array}{l}\text { Paints manufacturing, metal } \\
\text { refineries/production, coal } \\
\text { burning, } \\
\text { metal refineries/production, } \\
\text { chemical industry }\end{array}$ & $\begin{array}{l}\text { (Popadic et al., 2013; Brady et } \\
\text { al., 2014; Chae et al., 2014) }\end{array}$ & 298.22 & $\begin{array}{l}\text { Egyptian } \\
\text { Mediterranean coast }\end{array}$ & $\begin{array}{l}\text { (El-Sorogy et al., } \\
2016 \text { ) }\end{array}$ \\
\hline $\mathrm{Hg}$ & $\begin{array}{l}\text { Acid mine, mine, coke, ore, paints } \\
\text { manufacturing, calcine waste } \\
\text { materials, paper manufacturing, } \\
\text { volcanic eruptions, pesticides }\end{array}$ & $\begin{array}{l}\text { (Osher et al., 2006; Choi et al., } \\
\text { 2007; Nieto et al., 2007; } \\
\text { Popadic et al., 2013; Brady et } \\
\text { al., 2014; Looi et al., 2015) }\end{array}$ & 22.07 & $\begin{array}{l}\text { Kongsfjorden in } \\
\text { Norway }\end{array}$ & $\begin{array}{l}\text { (Z. Lu et al., } \\
\text { 2013) }\end{array}$ \\
\hline
\end{tabular}

There have been few studies on the temporal trend of metal contamination on a global scale. The temporal trend of metal contamination, as presented in several sources, could not be determined accurately due to differences in sampling sites, sampling methods and detection methods. Taking China as a case, concentrations of metals $\mathrm{Cr}, \mathrm{Cu}, \mathrm{Cd}, \mathrm{Ba}, \mathrm{Pb}$ and $\mathrm{U}$ in Hainan Island have risen in the recent 140 years by using coral skeleton as an indicator, while concentrations of metals $\mathrm{Mn}, \mathrm{Ni}, \mathrm{Zn}$ and $\mathrm{Sr}$ have been relatively steady. However, a case study in one of the Xisha Islands in South China Sea showed that concentrations of most metals were steady except Ni (Song et al., 2014). Another study in Liaodong Bay located in the northwest Bohai Sea indicated that over the last one hundred years, concentrations of $\mathrm{Cd}, \mathrm{Hg}, \mathrm{Zn}$ and $\mathrm{Pb}$ increased abruptly after the late 1970s (Xu et al., 2009). 


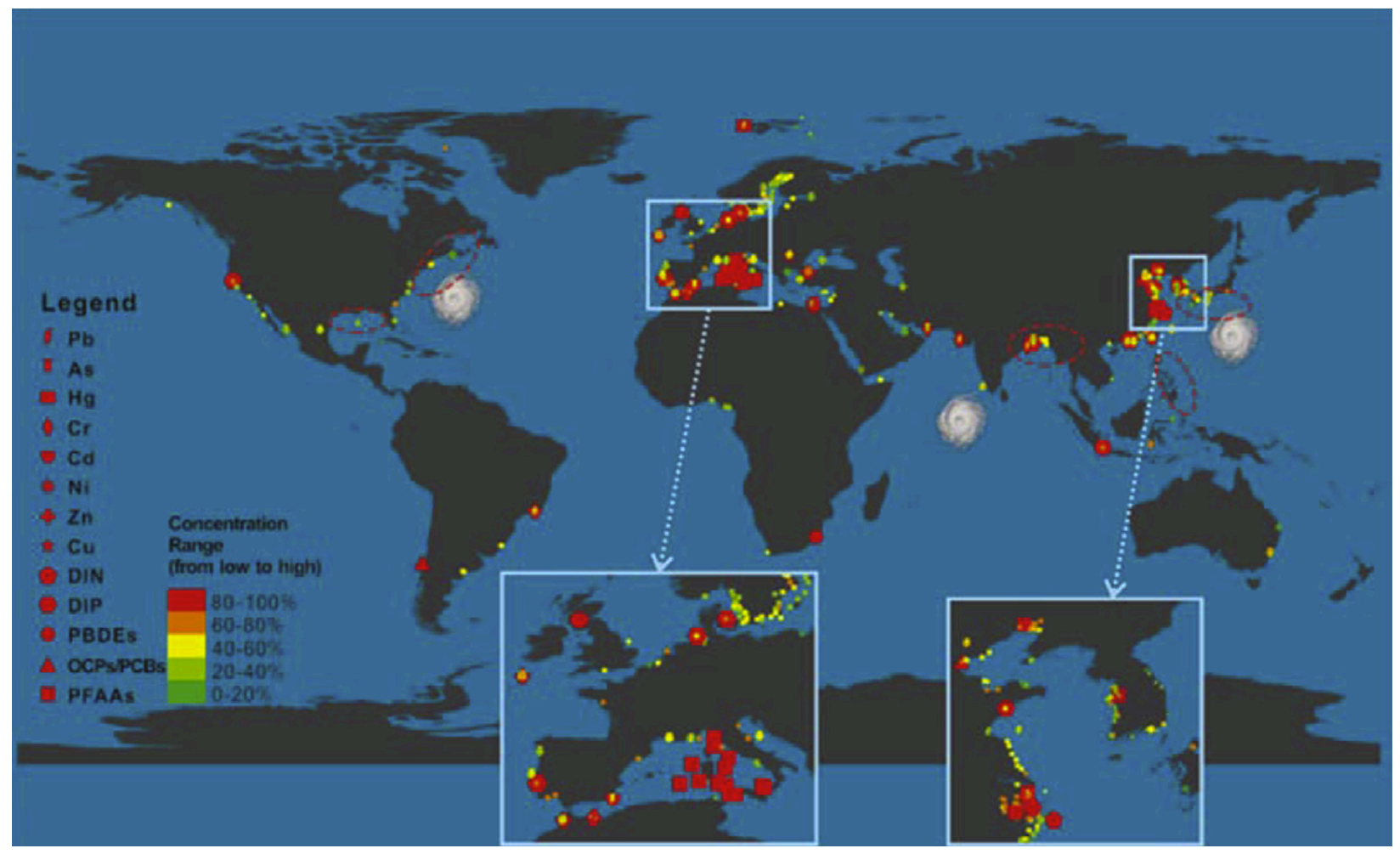

Fig 2. Global distributions of contaminants along the coast. Different shapes represent different contaminants. For each chemical, the concentrations were normalized by logarithm and then classified into five groups by equal interval. Different colors from green to red show different ranges, and red presented the top $20 \%$ range. The cyclone figure indicates the places where suffer most from storms. The thermometer figures show the coastal water which is getting hotter than other regions. (For interpretation of the references to color in this figure legend, the reader is referred to the Web version of this article.)

\subsubsection{Sources of metal contamination}

We can see the potential sources of each metal summarized in Table 1, which shows that each individual metal may come from various sources and some metals have the same sources. Coastal mining activities could cause the contamination of $\mathrm{Cu}, \mathrm{Zn}, \mathrm{Cd}$ and $\mathrm{Hg}$. Oil spill could increase the concentrations of $\mathrm{Cu}, \mathrm{Zn}, \mathrm{Pb}$ and $\mathrm{Cr}$. Paints manufacturing might lead to the pollution of $\mathrm{Cu}, \mathrm{Zn}, \mathrm{Cr}$, As and $\mathrm{Hg}$.

\subsection{Pervasive existence of persistent organic pollutants}

Halogen elements like fluorine, chlorine and bromine are extracted from sea water and then added during synthesis of organic compounds, such as pesticides, flame retardants and fabric coating. With extensive applications, increasing occurrence of these halogenated organic chemicals was discovered in the coastal environments. Due to the properties of stable structure, bioaccumulation and long-range transport, some of these halogenated organic chemicals have been listed as persistent organic pollutants (POPs) in the Stockholm Convention, including legacy contaminants such as organochlorine pesticides (OCPs), polychlorinated 
biphenyls (PCBs) and polybromodiphenyl ethers (PBDEs), and emerging pollutants such as hexabromocyclododecanes (HBCDs), Dechlorane Plus (DP) and Perfluoroalkyl Substances

(PFASs) (Kim and Yoon, 2014; Han and Currell, 2016; Mwangi et al., 2016; Meng et al., 2017).

\subsubsection{Global distribution along the coast}

Monitoring of POPs in coastal environments has been mainly conducted in China and Europe, with investigations rarely carried out in North and South America, Africa and Oceania (Fig. 2). Available monitoring results (Tables S3-S5) show that coasts in China and Europe were more contaminated than other areas, and this may be due to scarcity of information from other regions of the world. The highest concentration of PBDEs in the coastal surface sediment reached $1500 \mathrm{ng} \mathrm{g}^{-1}$ at River Clyde Estuary, UK (Vane et al., 2010). The highest PCBs level in sediment reached $13000 \mathrm{ng} \mathrm{g}^{-1}$ at Lenga Estuary, Chile, which is located in a nature sanctuary but influenced by the heavy industrialization and economic development of its adjacent coast (Pozo et al., 2014). And the highest concentration of PFAAs in coastal sea water reached 1240 ng L $\mathrm{L}^{-1}$ at the Daling Estuary, China (Wang et al., 2016) which was contaminated by upstream fluorine chemical parks (Wang et al., 2015; Zhu et al., 2015). Emissions from land-based activities were considered to be the major source of POPs in the coastal area, especially in estuaries, and higher levels of POPs usually occurred in populated, urbanized and industrialized areas.

\subsubsection{Temporal trend}

Marine organisms play a crucial role in the transport of POPs via the food web. In order to protect the coastal ecosystems and human health from the increasing level of POPs, marine organisms e.g. mollusks (Sericano et al., 2014; Grotti et al., 2016), fish (Nyberg et al., 2015; Cincinelli et al., 2016), sea birds (Elliott and Elliott, 2013; Miller et al., 2015) and mammals (Lam et al., 2016) have been used as biomarkers to trace temporal trends of POPs (Table 2). Monitoring programs such as "Mussel Watch" of the US from 1986, "Swedish National Monitoring Program for Contaminants in Marine Biota" from 1969 and "Environmental Specimen Bank" initiated by Germany from the 1980s have conducted long term observations for coastal environmental changes (Sericano et al., 2014; Nyberg et al., 2015; Grotti et al., 2016). Decreases of DDTs, PCBs, HCHs and PBDEs and increases of HBCD and PFAAs were reflected by coastal organisms. For many compound groups, the downward temporal trends were in response to regulation or voluntary discontinuation of use (Kim and Yoon, 2014; Law, 2014).

\subsection{Warming coast under climate change}

Due to their unique geographical locations, the coastal zones are the most vulnerable ecosystems to the impacts of climate change. Climate change is expected to affect the coastal zones by altering the ocean temperature and circulation patterns, frequency and intensity of 
coastal storms, precipitation patterns and subsequent delivery of freshwater, nutrients, sediments, and rate of rising sealevel (Scavia et al., 2002; Han et al., 2010; Darby et al., 2016).

Table 2. Temporal trend of POPs.

\begin{tabular}{|c|c|c|c|c|c|}
\hline Temporal trend & Chemical & Organism & $\begin{array}{l}\text { Time } \\
\text { period }\end{array}$ & Location & Reference \\
\hline Decreased & DDTs & Bivalves & $\begin{array}{l}1985 \\
-2010\end{array}$ & $\begin{array}{l}\text { East Coast, Gulf Coast and West coast of the } \\
\text { USA }\end{array}$ & $\begin{array}{l}\text { (Sericano et al., } \\
\text { 2014) }\end{array}$ \\
\hline Decreased & $\begin{array}{l}\text { PCB-153 } \\
\text { PCB-118 }\end{array}$ & $\begin{array}{l}\text { Herring (Clupea harengus) } \\
\text { European perch (Perca fluviatilis) }\end{array}$ & $\begin{array}{l}1987 \\
-2012\end{array}$ & Swedish coast & $\begin{array}{l}\text { (Nyberg et al., } \\
\text { 2015) }\end{array}$ \\
\hline Decreased & DDE & $\begin{array}{l}\text { Baltic cod (Gadus morhua) } \\
\text { Eelpout (Zoarces viviparous) }\end{array}$ & $\begin{array}{l}1969 \\
-2012\end{array}$ & & \\
\hline Decreased & $\gamma-\mathrm{HCH}$ & $\begin{array}{l}\text { Blue mussel (Mytilus edulis) } \\
\text { guillemot (Uria aalge) }\end{array}$ & $\begin{array}{l}1981 \\
-2012\end{array}$ & & \\
\hline Decreased & $\beta-\mathrm{HCH}$ & & $\begin{array}{l}1987 \\
-2012\end{array}$ & & \\
\hline Decreased & НСB & & $\begin{array}{l}1979 \\
-2012\end{array}$ & & \\
\hline $\begin{array}{l}\text { Increased and then decreased from } \\
1990 \mathrm{~s}\end{array}$ & PBDEs & Double crested cormorants & $\begin{array}{l}1979 \\
-2011\end{array}$ & $\begin{array}{l}\text { Salish Sea region, the west coast of North } \\
\text { America }\end{array}$ & (Miller et al., 2015) \\
\hline $\begin{array}{l}\text { Increased and then decreased from } \\
2000 \mathrm{~s}\end{array}$ & & Great blue herons & $\begin{array}{l}1987 \\
-2012\end{array}$ & & \\
\hline $\begin{array}{l}\text { Decreased and then fluctuated } \\
\text { Fluctuated }\end{array}$ & $\begin{array}{l}\text { PCBs } \\
\text { PAHs }\end{array}$ & scallop (Adamussium colbecki) & $\begin{array}{l}1996 \\
-2009\end{array}$ & Terra Nova Bay, Ross Sea, Antarctica & (Grotti et al., 2016) \\
\hline Increased & $\mathrm{HBCD}$ & $\begin{array}{l}\text { Leach's storm-petrel (Oceanodroma } \\
\text { leucorhoa) }\end{array}$ & $\begin{array}{l}1994 \\
-2011\end{array}$ & Pacific coast of British Columbia, Canada & (Miller et al., 2014) \\
\hline Increased & PFAAs & $\begin{array}{l}\text { Indo-Pacific humpback dolphin (Sousa } \\
\text { chinensis) }\end{array}$ & $\begin{array}{l}2002 \\
-2014\end{array}$ & Hong Kong, China & (Lam et al., 2016) \\
\hline Increased & & $\begin{array}{l}\text { Finless porpoise (Neophocaena } \\
\text { phocaenoides) }\end{array}$ & $\begin{array}{l}2004 \\
-2014\end{array}$ & & \\
\hline
\end{tabular}

The world's oceans are considered to be the main sink of additional thermal energy arising from the increasing level of atmospheric greenhouse gases. As a result, the trend of increased surface sea temperature (SST) is about $0.114^{\circ} \mathrm{C}$ per decade over the period from 1950 to 2014 (Karl et al., 2015). The distribution of ocean heating shows an uneven pattern (Fig. 2). The SSTs of coastal water in Western Europe, North Africa, Western Canada, Western America, South and Eastern Asia and Polar Regions have increased more than other regions (Smith et al., 2008; Cheung et al., 2013). The uneven distribution of heating would strongly influence the ocean currents, local climates and ecosystems. Changes of the thermohaline circulation as a result of disproportionate heating have exacerbated the climatic phenomena such as the El Ninõ Southern Oscillation (ENSO) (Hoegh Guldberg and Bruno, 2010). As a result of the relatively higher rate of increasing temperature in polar oceans, the volume of polar ice is steadily decreasing which, together with ocean thermal expansion, has significant impacts on sea level rise. Overall, both regional climatic patterns and the rate of sea level rise are directly affected by warming oceans which have profound implications for coastal zones.

An investigation started in 1970 observed an increased number and proportion of hurricanes reaching higher intensity categories (Webster et al., 2005). The intensity of tropical cyclones is predicted to increase $2 \mathrm{e} 11 \%$ by 2100 , and the globally averaged frequency of tropical cyclones will decrease by 6e34\% (Knutson et al., 2010). According to instrument records, the Western North Pacific has been the most prolific tropical cyclone basin; both in terms of the overall number of tropical cyclones (about $30 \%$ of global activity) and their peak wind intensities (Fig. 2). However, in recent years both the North Atlantic and North Indian Oceans have suffered the most severe economic losses because of landfalls in well-developed and densely populated areas (Woodruff et al., 2013). Low-lying coastal regions including Western Europe, South Asia 
and Eastern America are much more vulnerable to storm-induced floods (Michener et al., 1997; Coumou and Rahmstorf, 2012; Czajkowski et al., 2017).

Sea-level rise is another foreseeable change with many concerns. Average sea level has increased $0.19 \mathrm{~m}$ from 1901 to 2010 globally (IPCC Fifth Assessment Report, 2013). It is estimated that more than $90 \%$ of coastal areas will experience sea level rise exceeding the global estimate of $0.2 \mathrm{~m}$ by 2040 with a $2^{\circ}$ warming (Jevrejeva et al., 2016). Satellite altimetry shows that sea level is not rising uniformly. In some regions like the Western Pacific, North Indian Ocean and Gulf of Mexico, the sea level has risen faster than the global average, while the relative sea-level at the Eastern Pacific has decreased (Nicholls and Cazenave, 2010). The influence of rising sea level on coastal zones will largely depends on regional features. The small islands distributed in the Indian Ocean, the Caribbean and Pacific Ocean such as the Maldives or Tuvalu will face the complete submergence during the $21^{\text {st }}$ century. Most coastal regions in the South, Southeast and East Asia with dense population and low-lying elevation will be highly threatened with appreciable rates of relative land subsidence (Nicholls and Cazenave, 2010; Woodruff et al., 2013; Spencer et al., 2016).

\section{Impacts of human activities and climate change on coastal marine ecosystems}

\subsection{Coastal eutrophication}

Harmful algal blooms and hypoxia are the two most acute consequences of eutrophication. In direct response to nutrient enrichment, the visible ecosystem changes include high levels of chla, decreased water transparency and algal blooms which are sometimes toxic. In more advanced stages, high bacteria levels, scums, hypoxia and even anoxia are observed (Kitsiou, 2011; Jakobsen and Markager, 2016). It will promote the formation of reduced compounds and accumulation of particulate organic matter causing higher adverse (toxic) effects on aquatic animals. Dead zones in the coastal oceans have spread exponentially and have serious consequences for more than 400 systems throughout the world since the 1960s (Diaz and Rosenberg, 2008). A total area of more than $245,000 \mathrm{~km} 2$ is affected. The Gulf of Mexico and the northwestern shelf areas of Black Sea are two of the most wellknown hypoxic areas (Selman et al., 2008). Increased nutrient loading also results in biological diversity losses, greater susceptibility to disturbances, and the decline of ecosystem services (Carstensen et al., 2011). In addition to land reclamation and aquaculture activities, nutrient over-enrichment is also regarded as a major cause of the decline of seagrasses, coral reefs, mangroves and salt marshes worldwide (Szmant, 2002; Lovelock et al., 2009; Waycott et al., 2009; Deegan et al., 2012; Feller et al., 2015).

\subsection{Metal contamination}

Physiological damage as a result of long term exposure to high concentrations of metals can potentially change the ultrastructure of cells. For instance, $\mathrm{Cu}, \mathrm{Pb}$ and $\mathrm{As}$ could cause the 
ultrastructure of Sargrassum pallidum cells anomalous and aberrant (Miao et al., 2014). Metals can also inhibit the activity of enzyme and affect the osmotic pressure (Manahan, 2011). By altering the microstructure of organisms, metals could impact the growth and sensitivity of species. However, this kind of response to metals varies greatly among assemblages (Dauvin, 2008). For example, $\mathrm{Cd}, \mathrm{Cr}, \mathrm{Pb}$ and their mixtures could affect the survival rate of juveniles of scallop Argopecten ventricosus, and Cd demonstrated the most obvious effect (SobrinoFigueroa et al., 2007). Metals could affect the organisms in higher trophic levels of the food web through bioaccumulation and bio-magnification processes, resulting in important influences on human life and ecosystems (Ip et al., 2007). For instance, the concentrations of $\mathrm{Zn}, \mathrm{Cu}$ and $\mathrm{Hg}$ are high enough to cause toxic effects in large animals such as dolphins (Gui et al., 2017). And very high concentration of $\mathrm{Cd}$ was observed in the liver of some top predator fish in the Gulf of Oman (de Mora et al., 2004).

As an important source of metal contamination, oil spill brings about significant influences on coastal ecosystems. The first characteristic of oil spill is the increase of concentrations of total petroleum hydrocarbons in seawater, soils in coastal areas such as salt marshes, fish muscle and sandy beach micro benthic community (Jung et al., 2011; Yu et al., 2013). It will result in the complete mortality of plants, Spartina alterniflora and Juncus roemerianus, as well as changes of the microbial community, vegetation structure, biomass and function of salt marshes in the coastal ecosystem (Beazley et al., 2012; Lin and Mendelssohn, 2012; Lamendella et al., 2014). Oil spills have affected the wetlands such as in Mississippi River Delta Ecosystem, which has further influenced fish production, oil and gas supply in the wetlands (Mendelssohn et al., 2012).

\subsection{POPs contamination}

According to the latest toxicity tests in lab studies (USEPA ECOTOX database), POPs can affect coastal organisms in various ways. For example, lindane could reduce algae population, interfere with crustaceans, molluscs and fish via biochemical, enzyme and hormone effects and even kill them. PCBs could interfere with fish, invertebrates and reptiles via enzyme and genetic effects. PBDEs could kill crustaceans, affect the gene expression of fish and reduce the population growth rate of algae. PFOA could reduce the population growth rate of algae and affect the growth of invertebrates.

Field studies usually relied on correlations between tissue concentrations of contaminants and effects. The most representative example of the observed effect from POPs was coastal birds. Improved reproduction of brown pelicans (Pelecanus occidentalis) off the southern California coast reflected improved eggshell conditions and better egg survival with declined DDE contamination in their food source (Anderson et al., 1975). The shell thickness in brown booby (Sula leucogaster) eggs in the coast of Mexico decreased since 1920 and returned to pre-DDT values in the 2000s (Mellink et al., 2009). With the phasing out of traditional POPs, the alternative chemicals are less toxic. Therefore, the environmental levels of emerging POPs did not reach the toxicity level, so effects in the field were hard to be observed. 
Several studies have illustrated the bioaccumulation and biomagnification of POPs in the food web. At the Pearl River Estuary in South China, biomagnification of PCBs, PBDEs and DDE was observed between Bombay duck and Tapertail anchovy (Sun et al., 2015). As apex predators, the concentrations of DDTs in Indo-Pacific humpback dolphins there increased by a factor of 212 compared with their prey fish (Gui et al., 2014). That the predators at higher trophic level are at risk is a major concern.

\subsection{Impacts of climate change}

At the global scale, storm-induced coastal floods, ocean acidification and sea-level rise have already affected the ecosystem service functions of coastal zones.

Extreme storms may act as a major destructive force on the structure governing the coastal ecosystems. Hurricane events can result in direct ecosystem conversion from one state into another (Michener et al., 1997). Salt marshes, mangroves and other estuarine ecosystems could be destroyed after hurricanes. Mature systems could be changed into barren lands which would then be occupied by pioneer or opportunistic species. This may significantly change the productivity, bio-diversity and ecological processes of coastal communities. Although the benthic invertebrate community structure is observed to be less-affected after hurricane in short term (Taghon et al., 2017), more frequent storms would shape the hydrological patterns which is critical to the ecological processes in coastal zones. In addition, an increase of $10 \%-50 \%$ of runoff for global large coastal regions induced by climate change is projected (Jonsson et al., 2017), and more precipitation would bring more freshwater and nutrients to coastal ecosystems disturbing the food web structure.

Rising sea-level could inundate large coastal areas. Even assuming a conservative global warming scenario, $20 \%-70 \%$ of intertidal habitats are estimated to be replaced by subtidal habitats in the United States (Galbraith et al., 2002), and the losses of intertidal habitats will result in the decrease of relevant species including some macrophytes and shorebirds. With rising sea level inundating the coastal lands, salt water intrusion would lead to widespread soil salinization in coastal ecosystems. Soil salinization is found to increase plant nitrogen content, soil ammonium and soil total nitrogen, although soil nitrates and soil microbial biomass nitrogen in coastal ecosystems will decrease (Zhou et al., 2017). The changed nitrogen cycling would then alter species ranges. Stronger competitive species including some salt-tolerant herbs and grasses will likely replace other species, which will reduce diversity (Noto and Shurin, 2017). Due to higher resilience to salinity, salt marshes may dominate the regions which are previously covered by brackish marshes and mangrove forests. Although coastal communities have developed the ability to recover after the changes of environmental conditions, it is difficult for them to adapt to such rapid increases of sea level.

Furthermore, the impacts of climate change will be superimposed upon other anthropogenic stresses such as eutrophication, hypoxia and pollution (Canuel et al., 2012; Feller et al., 2015; Shin et al., 2016). The trend of accretion of atmospheric $\mathrm{CO}_{2}$ concentration has resulted in ocean acidification which has already reduced the diversity of coral reef communities (Hoegh- 
Guldberg et al., 2007). In addition, eutrophication is found to facilitate this process and increase the susceptibility of coastal water to acidification (Cai et al., 2011). Excessive production of algae in coastal waters will both consume oxygen and produce carbon dioxide, and eventually increases acidity. Moreover, increased precipitations and runoff induced by climate change will potentially bring more nutrients and pollutants to coastal zones which can alter the biogeochemical processes. Besides, the bioavailability and activity of contaminants would be promoted under warmer temperature, further increasing the potential risk of toxics on coastal organisms.

\section{Sustainable management of coastal marine ecosystems}

Mapping the global distribution of nutrients, metals and POPs contamination show that the coasts of the Eastern Atlantic and Western Pacific were hotspots where the highest concentrations of several pollutants were found (Fig. 2). Worldwide high levels of PFAAs, DIP, $\mathrm{Cu}, \mathrm{Zn}, \mathrm{Cd}$ and $\mathrm{Pb}$ were found around the Mediterranean Sea at eastern Atlantic. Top levels of PFAAs, OCPs and PCBs, DIP and DIN were found around the Bohai Sea and Yellow Sea at western Pacific. These are also the regions mostly affected by warming climate. Coasts of Western Europe, North Africa, Southeast Asia, North Indian Ocean and North Atlantic are facing higher rates of heating and sea level rise. More intensive storms may hit the coasts of Eastern Atlantic and Western Pacific. Low-lying coasts including Southeast Asia and Western Europe may suffer most from the impacts of climate change. These hotspots share the same characteristics of great population, developed industry and (semi-) closed sea. The threats faced by them have the potential to invoke regime shifts in coastal ecosystems adversely affecting the beneficial ecosystem services they provide.

In view of the present challenges in the coastal zone, an effective and timely governance and management of coastal marine ecosystems is fundamentally important for maintaining the valuable functions and services they provided. From a complex system perspective, it is not possible to separately consider land-based impacts and coastal governance. Coastal zone in particular is the sink for many of the products and wastes of human activities and it requires management in a much larger context.

\subsection{Rate coastal marine capital}

In order to value and sustainably manage coastal zone, a clear censor of the total species in the coastal marine ecosystem is required. The most commonly applied method for the estimation of biomass is using different sizes of transect quadrate, which will calculate the amount of phytoplankton, zooplankton, plants and animals in coastal marine ecosystems (Cushing, 1958; Strickland and Parsons, 1972; McKenzie, 2003; Gross et al., 2014; Alcaraz et al., 2016; Borja et al., 2016). Diversity of coastal marine ecosystems is indicated by Pearson's correlation matrix, Shannon-Wiener diversity index and Pielou evenness (Hardikar et al., 2017). Human appropriation of net primary production (HANPP) is a useful index to estimate the human impacts on the coastal marine ecosystems, which takes the biomass index of phytoplankton, 
zooplankton, seagrass, fish, crabs, squids and mollusks together (Sjafrie et al., 2017). Daily Egg Production Method (DEGM) is developed for stock assessment of marine fishes, which has been applied to at least 18 species of small pelagic fishes (Ward et al., 2015). At the global scale, climate-based model and remote sensing are ideal tools to estimate the biomass of coastal marine ecosystems (Hutchison et al., 2014; O'Donnell and Schalles, 2016).

A 'gross marine product' (GMP) index would be invaluable for achieving the marine focused sustainable development goal (SDG). It can provide a measure of marine ecosystem goods and services on a national or global scale, derived from estimates for individual oceans. More international research will be necessary to underpin these estimates. The results would inform decision makers, the private sector and the public on how they could help to achieve SDG 14, as well as the 60 targets across most of the 17 SDGs that are relevant to the sustainable development of coastal zones. An integrated program that measures, monitors and assesses the health of human-ocean systems should oversee their sustainability (Lu et al., 2016).

\subsection{Integrated management of land-ocean interaction in the coastal zone}

After being embedded into the Future Earth program named as Future Earth Coasts since 2015, Land-Ocean Interactions in the Coastal Zone (LOICZ) project has extended its research area to understand the drivers and social-environmental impacts of global environmental change in coastal zones. Under the program, much of the research will mainly focus on the modification of fluxes of nutrients, sediments, water and air to coastal zones in response to future climate conditions (Regnier et al., 2013; Xu et al., 2016). Excess nutrient inputs and increasing pollution of heavy metals and emerging pollutants are the major consequences of land-ocean interaction in the coastal zones, which could be an important part of Future Earth Coasts program (Ramesh et al., 2015).

Special priority for the study of nutrient cycling mechanisms should be given to the land-based sources including industrial emission and agricultural runoffs. For point sources, nutrient discharge standards and total quantity control should be implemented. The major non-point control projects at present includes Barcelona Convention focusing on reduction of nutrient fluxes from terrestrial sources, the Coastal Nonpoint Pollution Control Program established in 1990 by the Environmental Protection Agency (EPA) of the United States with a goal to reduce polluted runoff to coastal waters, and the EU Nitrates Directive (Monteny, 2001; Ulen and Weyhenmeyer, 2007; Dowd et al., 2008). The residence time of metals in seawater and sediment as well as their diffusion range should be studied and human activities must be managed to reduce the ecological risks. Reduction of emissions on land and promotion of capacity in coasts are the two ways to reduce the risks from POPs. For example, land-ocean interaction was improved by promoting water exchange for tidal flat restoration in Japan (Matsuda and Kokubu, 2016). Systematic identification of combined ecotoxicological effects from POPs and other pollutants is needed for an integrated management of coastal zone. Future studies should be focused on interactions between nutrients cycling (especially nitrogen and phosphorus) and other toxic chemicals (POPs, metals, and so on). 
Diverse communities and international organizations involved in coastal and ocean management should work together to collaborate for sustainable ocean and coastal planning. The great challenge for Future Earth Coasts project is to develop a framework within which constraints to sustainable development can be analyzed and addressed in order to be considered in the SDGs context. How to balance the requirements from scientists, engineers, social communities and governments on coastal management to achieve the SDGs is also an important issue.

\subsection{Integrated global observation system for coastal zone}

Monitoring of the environmental pollutants and climate related parameters is the foundation of risk assessment and management. It is essential to establish an integrated global observation system including real-time monitoring to provide a scientific basis for the rational development, utilization and protection of coastal areas (Alverson, 2008). Regional alliances have been established while it is challenging to implement an integrated observation system for coastal zone at the global level in a short time.

The present monitoring program mainly includes climate monitoring and prediction; biological and abiotic resources; monitoring of water physics, chemistry and biology parameters; and realtime monitoring of harmful algal blooms. However, POPs, heavy metal and oil spill are not included in the major monitoring program. At present monitoring of POPs, heavy metal and oil spill varies in different countries and regions, while long-term monitoring greatly relies on national or regional programs rather than individual research.

Large gaps exist in nation's ability to provide comprehensive monitoring infrastructure, number of observation stations, and data inconsistency between developing and developed countries (Taylor, 2009; Li et al., 2015; Eschenbach, 2017). The existing data are often inconsistent in terms of parameters measured, indicators used and the scale at which data are reported. Available data still cannot meet the needs of projection at global or regional scale. Taking eutrophication as an example, comprehensive coastal surveys have been undertaken in the United States, European Union, Asia and Australia for the past years, all of which have the most comprehensive coastal data on eutrophication. However, even within the United States and Europe, the quality, consistency and availability of water quality data varies (Cosme and Hauschild, 2016). Developing countries should collaborate with developed countries to build capacity in observing, data mining and statistics. Scientists and governments need to design standards and consistent methods and instrumentation for data collection. Cooperation among authorities and agencies will be more effective if partners collect data according to agreed definitions, specifications, methodologies and formats (Lu et al., 2015).

The coastal zone has been greatly modified by anthropogenic activities, which should be monitored as an important part for the implementation of an integrated global observation system. Ocean Observations Panel for Climate (OOPC) under Global Ocean Observing System (GOOS) have recognized the need for sustainable ocean observations for climate research and the increased need to connect to societal issues in the coastal zones. Not only should the 
biogeochemical parameters be monitored, but also to establish a system that can make quick responses to emergency events. The improvement of integrated coastal observation system will depend on not only the layout of observation equipment, but also the capacity of an integrated ground-air-space observation linkage and cooperation.

\subsection{Coastal ecosystem-based management}

The incorporation of ecosystem services into environmental management is receiving increasing global attention. Ecosystem-based management (EBM) is an integrated approach to management that considers the entire ecosystem, including humans, and the cumulative impacts of different sectors (McLeod et al., 2005; Curtin and Prellezo, 2010). Its focus is to maintain ecosystem services and functions and to manage human activities based on ecosystems. Taking coastal mining as an example, not only the distribution and regions for exploitation and utilization should be considered, but also its impacts on the surrounding coastal ecosystems and the restoration of ecosystems after mining activities.

Most of the marine and coastal processes are affected by multiple stressors. Pollution of excess nutrients, metals, and persistent organic pollutants due to intensive human activities should be managed among different sectors and can be prevented by spatial planning in the coastal zone, which can provide a way to determine what activity should be occurring where, with less impact and less user conflict by regulating different human uses in an area. Salt marsh degradation can be mitigated by the regulation of activities of land reclamation, pollution discharged into estuaries, and run-off of chemical fertilizers. Spatially-explicit management of areas for multiple uses through spatial planning in the coastal zone, such as designation of marine protected areas, can allow managers to safeguard areas most critical for ecosystem function and the delivery of ecosystem services. It can also provide needed conservation of areas that are vulnerable to the extreme climate events such as storm-induced coastal floods.

EBM can provide a robust management strategy considering the effects of cumulative impacts of human activities. However, it usually considers the ecological factors, processes and stressors in an ecosystem, such as energy, climate, habitat restoration, primary productivity, especially fisheries. Even though environmental sustainability and socio-economic factors are included in the concept of EBM, pollutants such as nutrients, metals and POPs are not considered in its application (Kluger et al., 2015; Thrush et al., 2016; Yanezarancibia et al., 2015). However, those pollutants could be potential stressors on the coastal ecosystem by a combined exposure, although each pollutant may be at very low level. Currently established legal frameworks simply focusing on pollution control may not serve well under changing climate. Therefore, it is necessary to evaluate the ecological impacts of nutrients, metals and POPs and consider their cumulative effects under climate change. From the perspective of ecosystem stability and restoration, it is important to advance the scientific knowledge of the cumulative, integrative and interacting effects of climate change and human activities including eutrophication, toxic pollution and habitat destruction. 


\section{Funding}

The authors appreciate support from the China Key National Research and Development Program (2017YFC0505704), National Natural Science Foundation of China for grant (No. 71761147001 and No. 41420104004), Key R \& D Program of the Chinese Academy of Sciences (KFZD-SW-322), and the UNEP International Resource Panel with the Small Scale Funding Agreement (DTIE16-SC057).

\section{Author contributions}

Y. Lu conceived the idea and study design. J. Yuan, X. Lu, C. Su, Y. Zhang, C. Wang, X. Cao, Q. Li, and $Y$. Lu collected and analyzed data, and drafted the paper. All authors contributed to the analysis and interpretation, and commented on the draft paper. Y. Lu, J. Su, V. Ittekkot, R. Garbutt, and S. Fletcher revised the paper.

\section{Acknowledgments}

This paper represents a synthesis of the information reviewed and recommendations made at the International Symposium on Sustainable Coastal Ecosystems held in Beijing on 11-14 January 2017. We are grateful to Kenneth Sherman, Jon Samseth, Nancy Lewis, Sang-Dai Park, Soman Kunjupillai, Shu-min Huang, Valentin Sergienko, John Burke Burnett, Jun Sun, Xiaoxia Sun, Hui Liu, Mohamed Saber, and Wei Liu for their participation in discussions. We would also like to thank the editors and reviewers for their valuable comments and suggestions.

\section{Appendix A. Supplementary data}

Supplementary data related to this article can be found at https://doi.org/10.1016/j.envpol.2018.04.016.

\section{References}

Alaoui, A.M., Choura, M., Maanan, M., Zourarah, B., Robin, M., Conceiçao, M.F., Andrade, C., Khalid, M., Carruesco, C., 2010. Metal fluxes to the sediments of the Moulay Bousselham lagoon, Morocco. Environ. Earth Sci. 61 (2), 275-286.

Alcaraz, M., Calbet, A., Isari, S., Irigoien, X., Trepat, I., Saiz, E., 2016. Variability of mesozooplankton biomass and individual size in a coast-offshore transect in the Catalan Sea: relationships with chlorophyll a and hydrographic features. Sci. Mar. 80 (S1), 79-87.

Alverson, K., 2008. Filling the gaps in GOOS. J. Ocean Technol. 3, 19-23.

Anderson, D.W., Jehl, J.R., Risebrough, R.W., Woods, L.A., Deweese, L.R., Edgecomb, W.G., 1975. Brown pelicans: improved reproduction off the southern California coast. Science 190 (4216), 806-808.

Beazley, M.J., Martinez, R.J., Rajan, S., Powell, J., Piceno, Y.M., Tom, L.M., Andersen, G.L., Hazen, T.C., Van Nostrand, J.D., Zhou, J., 2012. Microbial community analysis of a coastal salt marsh affected by the Deepwater Horizon oil spill. PLoS One 7 (7), e41305. 
Borges, R.C., Caldas, V.G., Lamego Simoes Filho, F.F., Ferreira, M.M., Franklin Lapa, C.M., 2014. Use of GIS for the evaluation of heavy metal contamination in the Cunha Canal watershed and west the Guanabara Bay, Rio de Janeiro, RJ. Mar. Pollut. Bull. 89 (1-2), 75-84.

Borja, A., Elliot, M., Andersen, J.H., Berg, T., Cartsensen, J., Halpern, B.S., Heiskanen, A.S., Korpinen, S., Lowndes, J.S.S., Martin, G., 2016. Overview of integrative assessment of marine systems: the Ecosystem Approach in practice. Front. Mar. Sci. 3 (55).

Brady, J.P., Ayoko, G.A., Martens, W.N., Goonetilleke, A., 2014. Temporal trends and bioavailability assessment of heavy metals in the sediments of Deception Bay, Queensland, Australia. Mar. Pollut. Bull. 89 (1), 464-472.

Brookes, J.D., Carey, C.C., 2011. Resilience to blooms. Science 334 (6052), 46-47. Cai, W.J., Hu, X.P., Huang, W.J., Murrell, M.C., Lehrter, J.C., Lohrenz, S.E., Chou, W.C., Zhai, W.D., Hollibaugh, J.T., Wang, Y.C., Zhao, P.S., Guo, X.H., Gundersen, K., Dai, M.H., Gong, G.C., 2011. Acidification of subsurface coastal waters enhanced by eutrophication. Nat. Geosci. 4 (11), 766-770.

Canuel, E.A., Cammer, S.S., McIntosh, H.A., Pondell, C.R., 2012. Climate change impacts on the organic carbon cycle at the land-ocean interface. Annu. Rev. Earth Planet Sci. 40 (1), 685-711.

Carstensen, J., Andersen, J.H., Gustafsson, B.G., Conley, D.J., 2014. Deoxygenation of the Baltic Sea during the last century. Proc. Natl. Acad. Sci. Unit. States Am. 111 (15), 56285633.

Carstensen, J., Sanchez-Camacho, M., Duarte, C.M., Krause-Jensen, D., Marba, N., 2011. Connecting the dots: responses of coastal ecosystems to changing nutrient concentrations. Environ. Sci. Technol. 45 (21), 9122-9132.

Chae, J.S., Choi, M.S., Song, Y.H., Um, I.K., Kim, J.G., 2014. Source identification of heavy metal contamination using metal association and $\mathrm{Pb}$ isotopes in Ulsan Bay sediments, East Sea, Korea. Mar. Pollut. Bull. 88 (1), 373-382.

Cheung, W.W.L., Watson, R., Pauly, D., 2013. Signature of ocean warming in global fisheries catch. Nature 497 (7449), 365-368.

Choi, M.-S., Yi, H.-I., Yang, S.Y., Lee, C.-B., Cha, H.-J., 2007. Identification of Pb sources in Yellow Sea sediments using stable $\mathrm{Pb}$ isotope ratios. Mar. Chem. 107 (2), 255-274.

Christensen, V., Coll, M., Piroddi, C., Steenbeek, J., Buszowski, J., Pauly, D., 2014. A century of fish biomass decline in the ocean. Mar. Ecol. Prog. Ser. 512, 155-166. 
Cincinelli, A., Martellini, T., Pozo, K., Kukucka, P., Audy, O., Corsolini, S., 2016. Trematomus bernacchii as an indicator of POP temporal trend in the Antarctic seawaters. Environ. Pollut. $217,19-25$.

Cosme, N., Hauschild, M.Z., 2016. Effect Factors for marine eutrophication in LCIA based on species sensitivity to hypoxia. Ecol. Indicat. 69, 453-462.

Costanza, R., d'Arge, R., De Groot, R., Farber, S., Grasso, M., Hannon, B., Limburg, K., Naeem, S., O'neill, R.V., Paruelo, J., 1997. The value of the world's ecosystem services and natural capital. Nature 387, 253-260.

Coumou, D., Rahmstorf, S., 2012. A decade of weather extremes. Nat. Clim. Change 2 (7), 491496.

Curtin, R., Prellezo, R., 2010. Understanding marine ecosystem based management: a literature review. Mar. Pol. 34 (5), 821-830.

Cushing, D., 1958. The estimation of carbon in phytoplankton. Rappt. Proces Verbaux Reunions, Conseil Perm. Intern. Exploration Mer 144, 32-33.

Czajkowski, J., Villarini, G., Montgomery, M., Michel-Kerjan, E., Goska, R., 2017. Assessing current and future freshwater flood risk from North Atlantic tropical cyclones via insurance claims. Sci. Rep. 7.

Darby, S.E., Hackney, C.R., Leyland, J., Kummu, M., Lauri, H., Parsons, D.R., Best, J.L., Nicholas, A.P., Aalto, R., 2016. Fluvial sediment supply to a mega-delta reduced by shifting tropicalcyclone activity. Nature 539 (7628), 276-279.

Dauvin, J.-C., 2008. Effects of heavy metal contamination on the microbenthic fauna in estuaries: the case of the Seine estuary. Mar. Pollut. Bull. 57 (1), 160-169.

de Mora, S., Fowler, S.W., Wyse, E., Azemard, S., 2004. Distribution of heavy metals in marine bivalves, fish and coastal sediments in the Gulf and Gulf of Oman. Mar. Pollut. Bull. 49 (5), $410-$ 424.

de Mutsert, K., Steenbeek, J., Lewis, K., Buszowski, J., Cowan, J.H., Christensen, V., 2016. Exploring effects of hypoxia on fish and fisheries in the northern Gulf of Mexico using a dynamic spatially explicit ecosystem model. Ecol. Model. 331, 142-150.

Deegan, L.A., Johnson, D.S., Warren, R.S., Peterson, B.J., Fleeger, J.W., Fagherazzi, S., Wollheim, W.M., 2012. Coastal eutrophication as a driver of salt marsh loss. Nature 490 (7420), 388-392.

Diaz, R.J., Rosenberg, R., 2008. Spreading dead zones and consequences for marine ecosystems. Science 321 (5891), 926-929. 
Doney, S.C., 2010. The growing human footprint on coastal and open-ocean biogeochemistry. Science 328 (5985), 1512-1516.

Dou, Y., Li, J., Zhao, J., Hu, B., Yang, S., 2013. Distribution, enrichment and source of heavy metals in surface sediments of the eastern Beibu Bay, South China Sea. Mar. Pollut. Bull. 67 (1), 137-145.

Dowd, B.M., Press, D., Huertos, M.L., 2008. Agricultural nonpoint source water pollution policy: the case of California's Central Coast. Agric. Ecosyst. Environ. 128 (3), 151-161.

Duce, R., LaRoche, J., Altieri, K., Arrigo, K., Baker, A., Capone, D., Cornell, S., Dentener, F., Galloway, J., Ganeshram, R., 2008. Impacts of atmospheric anthropogenic nitrogen on the open ocean. Science 320 (5878), 893-897.

El-Sorogy, A.S., Tawfik, M., Almadani, S.A., Attiah, A., 2016. Assessment of toxic metals in coastal sediments of the Rosetta area, Mediterranean Sea, Egypt. Environ. Earth Sci. 75 (5), 111.

Elliott, J.E., Elliott, K.H., 2013. Tracking marine pollution. Science 340 (6132), 556-558.

Erisman, J.W., Galloway, J.N., Seitzinger, S., Bleeker, A., Dise, N.B., Petrescu, A.R., Leach, A.M., de Vries, W., 2013. Consequences of human modification of the global nitrogen cycle. Phil. Trans. R. Soc. B 368 (1621), 20130116.

Eschenbach, C.A., 2017. Bridging the gap between observational oceanography and users. Ocean Sci. 13 (1), 161-173. FAO, 2013. Food and agriculture organization of the united nations. Cyprinus carpio.

Feller, I.C., Dangremond, E.M., Devlin, D.J., Lovelock, C.E., Proffitt, C.E., Rodriguez, W., 2015. Nutrient enrichment intensifies hurricane impact in scrub mangrove ecosystems in the Indian River Lagoon, Florida, USA. Ecology 96 (11), 2960-2972.

Ferreira, A.M., Marques, J.C., Seixas, S., 2017. Integrating marine ecosystem conservation and ecosystems services economic valuation: implications for coastal zones governance. Ecol. Indicat. 77, 114-122.

Fisher, R., O'Leary, R.A., Low-Choy, S., Mengersen, K., Knowlton, N., Brainard, R.E., Caley, M.J., 2015. Species richness on coral reefs and the pursuit of convergent global estimates. Curr. Biol. 25 (4), 500-505.

Galbraith, H., Jones, R., Park, R., Clough, J., Herrod-Julius, S., Harrington, B., Page, G., 2002. Global climate change and sea level rise: potential losses of intertidal habitat for shorebirds. Waterbirds 25 (2), 173-183. 
Gross, J., Flores, E.E., Schwendenmann, L., 2014. Stand structure and aboveground biomass of a Pelliciera rhizophorae mangrove forest, Gulf of Monitjo Ramsar site, Pacific Coast, Panama. Wetlands 34 (1), 55-65.

Grotti, M., Pizzini, S., Abelmoschi, M.L., Cozzi, G., Piazza, R., Soggia, F., 2016. Retrospective biomonitoring of chemical contamination in the marine coastal environment of Terra Nova Bay (Ross Sea, Antarctica) by environmental specimen banking. Chemosphere 165, 418-426.

Gui, D., Yu, R., He, X., Tu, Q., Chen, L., Wu, Y., 2014. Bioaccumulation and biomagnification of persistent organic pollutants in Indo-Pacific humpback dolphins (Sousa chinensis) from the Pearl River Estuary, China. Chemosphere 114, 106-113.

Gui, D., Yu, R., Karczmarski, L., Ding, Y., Zhang, H., Sun, Y., Zhang, M., Wu, Y., 2017. Spatiotemporal trends of heavy metals in Indo-Pacific humpback dolphins (Sousa chinensis) from the western Pearl River Estuary, China. Environ. Sci. Technol. 51 (3), 1848-1858.

Hale, R.L., Grimm, N.B., Vorosmarty, C.J., Fekete, B., 2015. Nitrogen and phosphorus fluxes from watersheds of the northeast US from 1930 to 2000: role of anthropogenic nutrient inputs, infrastructure, and runoff. Global Biogeochem. Cycles 29 (3), 341-356.

Halpern, B.S., Frazier, M., Potapenko, J., Casey, K.S., Koenig, K., Longo, C., Lowndes, J.S., Rockwood, R.C., Selig, E.R., Selkoe, K.A., 2015. Spatial and temporal changes in cumulative human impacts on the world's ocean. Nat. Commun. 6 (7615).

Halpern, B.S., Walbridge, S., Selkoe, K.A., Kappel, C.V., Micheli, F., D'Agrosa, C., Bruno, J.F., Casey, K.S., Ebert, C., Fox, H.E., 2008. A global map of human impact on marine ecosystems. Science 319 (5865), 948-952.

Han, D., Currell, M.J., 2016. Persistent organic pollutants in China's surface water systems. Sci. Total Environ. 580, 602-625.

Han, W.Q., Meehl, G.A., Rajagopalan, B., Fasullo, J.T., Hu, A.X., Lin, J.L., Large, W.G., Wang, J.W., Quan, X.W., Trenary, L.L., Wallcraft, A., Shinoda, T., Yeager, S., 2010. Patterns of Indian Ocean sea-level change in a warming climate. Nat. Geosci. 3 (8), 546-550.

Hardikar, R., Haridevi, C., Chowdhury, M., Shinde, N., Ram, A., Rokade, M., Rakesh, P., 2017. Seasonal distribution of phytoplankton and its association with physicochemical parameters in coastal waters of Malvan, west coast of India. Environ. Monit. Assess. 189 (4), 151.

Hoegh-Guldberg, O., Bruno, J.F., 2010. The impact of climate change on the World's marine ecosystems. Science 328 (5985), 1523-1528. 
Hoegh-Guldberg, O., Mumby, P.J., Hooten, A.J., Steneck, R.S., Greenfield, P., Gomez, E., Harvell, C.D., Sale, P.F., Edwards, A.J., Caldeira, K., Knowlton, N., Eakin, C.M., Iglesias-Prieto, R., Muthiga, N., Bradbury, R.H., Dubi, A., Hatziolos, M.E., 2007. Coral reefs under rapid climate change and ocean acidification. Science 318 (5857), 1737-1742.

Howarth, R.W., 2008. Coastal nitrogen pollution: a review of sources and trends globally and regionally. Harmful Algae 8 (1), 14-20.

Hutchison, J., Manica, A., Swetnam, R., Balmford, A., Spalding, M., 2014. Predicting global patterns in mangrove forest biomass. Conserv. Lett. 7 (3), 233-240. ICSU, ISSC, 2015. Review of the sustainable development goals: the science perspective. Paris: International Council for Science (ICSU).

Ip, C.C.M., Li, X.-D., Zhang, G., Wai, O.W.H., Li, Y.-S., 2007. Trace metal distribution in sediments of the Pearl River Estuary and the surrounding coastal area, South China. Environ. Pollut. 147 (2), 311-323.

Jakobsen, H.H., Markager, S., 2016. Carbon-to-chlorophyll ratio for phytoplankton in temperate coastal waters: seasonal patterns and relationship to nutrients. Limnol. Oceanogr. $61(5), 1853-1868$.

Jennerjahn, T.C., 2012. Biogeochemical response of tropical coastal systems to present and past environmental change. Earth Sci. Rev. 114 (1), 19-41.

Jevrejeva, S., Jackson, L.P., Riva, E.M., Grinsted, A., Moore, J.C., 2016. Coastal sea level rise with warming above 2 degrees C. Proc. Natl. Acad. Sci. U.S.A. 113 (47), 13342-13347.

Jonsson, S., Andersson, A., Nilsson, M.B., Skyllberg, U., Lundberg, E., Schaefer, J.K., Åkerblom, S., Bjorn, E., 2017. Terrestrial discharges mediate trophic shifts and enhance methylmercury accumulation in estuarine biota. Sci. Adv. 3 (1), 1-9.

Jung, J.-H., Kim, M., Yim, U.H., Ha, S.Y., An, J.G., Won, J.H., Han, G.M., Kim, N.S., Addison, R.F., Shim, W.J., 2011. Biomarker responses in pelagic and benthic fish over 1 year following the Hebei Spirit oil spill (Taean, Korea). Mar. Pollut. Bull. 62 (8), 1859-1866.

Karl, T.R., Arguez, A., Huang, B.Y., Lawrimore, J.H., McMahon, J.R., Menne, M.J., Peterson, T.C., Vose, R.S., Zhang, H.M., 2015. Possible artifacts of data biases in the recent global surface warming hiatus. Science 348 (6242), 1469-1472.

Keshavarzi, B., Ebrahimi, P., Moore, F., 2015. A GIS-based approach for detecting pollution sources and bioavailability of metals in coastal and marine sediments of Chabahar Bay, SE Iran. Chemie der Erde-Geochemistry 75 (2), 185-195. 
Kim, S.-K., Yoon, J., 2014. Chronological trends of emission, environmental level and human exposure of POPs over the last 10 years (1999-2010) in Korea: implication to science and policy. Sci. Total Environ. 470, 1346-1361.

Kitsiou, D., Karydis, Michael, 2011. Coastal marine eutrophication assessment: a review on data analysis. Environ. Int. 37 (4), 778-801.

Kluger, L.C., Taylor, M.H., Mendo, J., Tam, J., Wolff, M., 2015. Carrying capacity simulations as a tool for ecosystem-based management of a scallop aquaculture system. Ecol. Model. 331, 4455.

Knutson, T.R., McBride, J.L., Chan, J., Emanuel, K., Holland, G., Landsea, C., Held, I., Kossin, J.P., Srivastava, A.K., Sugi, M., 2010. Tropical cyclones and climate change. Nat. Geosci. 3 (3), 157163.

Lam, J.C.W., Lyu, J., Kwok, K.Y., Lam, P.K.S., 2016. Perfluoroalkyl substances (PFASs) in marine mammals from the south China Sea and their temporal changes 20022014: concern for alternatives of PFOS? Environ. Sci. Technol. 50 (13), 6728-6736.

Lamendella, R., Strutt, S., Borglin, S., Chakraborty, R., Tas, N., Mason, O., Hultman, J., Prestat, E., Hazen, T., Jansson, J., 2014. Assessment of the Deepwater Horizon oil spill impact on Gulf coast microbial communities. Front. Microbiol. 5 (130).

Lapointe, B.E., Herren, L.W., Debortoli, D.D., Vogel, M.A., 2015. Evidence of sewagedriven eutrophication and harmful algal blooms in Florida's Indian River Lagoon. Harmful Algae 43, 82102.

Law, R.J., 2014. An overview of time trends in organic contaminant concentrations in marine mammals: going up or down? Mar. Pollut. Bull. 82 (1-2), 7-10.

Li, R.Q., Li, Y.F., van den Brink, M., Woltjer, J., 2015. The capacities of institutions for the integration of ecosystem services in coastal strategic planning: the case of Jiaozhou Bay. Ocean Coast Manag. 107, 1-15.

Lin, Q., Mendelssohn, I.A., 2012. Impacts and recovery of the Deepwater Horizon oil spill on vegetation structure and function of coastal salt marshes in the northern Gulf of Mexico. Environ. Sci. Technol. 46 (7), 3737-3743.

Liu, S., Lou, S., Kuang, C., Huang, W., Chen, W., Zhang, J., Zhong, G., 2011. Water quality assessment by pollution-index method in the coastal waters of Hebei Province in western Bohai Sea, China. Mar. Pollut. Bull. 62 (10), 2220-2229.

Looi, L.J., Aris, A.Z., Yusoff, F.M., Hashim, Z., 2015. Mercury contamination in the estuaries and coastal sediments of the Strait of Malacca. Environ. Monit. Assess. 187 (1), 4099. 
Lovelock, C.E., Ball, M.C., Martin, K.C., Feller, I.C., 2009. Nutrient enrichment increases mortality of mangroves. PLoS One 4 (5), e5600.

Lu, Y.L., Yuan, J.J., Visbeck, M., Fletcher, S., He, G.Z., 2016. Rate oceans' capital to help achieve SDGs. Nature 537, 34-34.

Lu, Y.L., Nakicenovic, N., Visbeck, M., Stevance, A.S., 2015. Five priorities for the UN sustainable development goals. Nature 520 (7548), 432-433.

Lu, Z., Cai, M., Wang, J., Yin, Z., Yang, H., 2013. Levels and distribution of trace metals in surface sediments from Kongsfjorden, Svalbard, Norwegian Arctic. Environ. Geochem. Health 35 (2), 257-269.

Manahan, S.E., 2011. Fundamentals of Environmental Chemistry. CRC press.

Matsuda, O., Kokubu, H., 2016. Recent coastal environmental management based on new concept of Satoumi which promotes land-ocean interaction: a case study in Japan. Estuar. Coast Shelf Sci. 183, 179-186.

McKenzie, L., 2003. Guidelines for the Rapid Assessment of Seagrass Habitats in the Western Pacific. Department of Primary Industries, Queensland, 78p.

McLeod, K., Lubchenco, J., Palumbi, S., Rosenberg, A., 2005. Scientific consensus statement on marine ecosystem-based management. Compass 221, 1-21.

Mellink, E., Riojas-Lopez, M.E., Luevano-Esparza, J., 2009. Organchlorine content and shell thickness in brown booby (Sula leucogaster) eggs in the Gulf of California and the southern Pacific coast of Mexico. Environ. Pollut. 157 (7), 2184-2188.

Mendelssohn, I.A., Andersen, G.L., Baltz, D.M., Caffey, R.H., Carman, K.R., Fleeger, J.W., Joye, S.B., Lin, Q., Maltby, E., Overton, E.B., 2012. Oil impacts on coastal wetlands: implications for the Mississippi River Delta ecosystem after the Deepwater Horizon oil spill. Bioscience 62 (6), 562-574.

Meng, J., Hong, S., Wang, T., Li, Q., Yoon, S.J., Lu, Y., Giesy, J.P., Khim, J.S., 2017. Traditional and new POPs in environments along the Bohai and Yellow seas: an overview of China and South Korea. Chemosphere 169, 503-515.

Miao, L., Yan, W., Zhong, L., Xu, W., 2014. Effect of heavy metals (Cu, Pb, and As) on the ultrastructure of Sargassum pallidum in Daya Bay, China. Environ. Monit. Assess. 186 (1), 87-95.

Michener, W.K., Blood, E.R., Bildstein, K.L., Brinson, M.M., Gardner, L.R., 1997. Climate 
change, hurricanes and tropical storms, and rising sea level in coastal wetlands. Ecol. Appl. 7 (3), 770-801.

Miller, A., Elliott, J.E., Elliott, K.H., Guigueno, M.F., Wilson, L.K., Lee, S., Idrissi, A., 2014. Spatial and temporal trends in brominated flame retardants in seabirds from the Pacific coast of Canada. Environ. Pollut. 195, 48-55.

Miller, A., Elliott, J.E., Elliott, K.H., Guigueno, M.F., Wilson, L.K., Lee, S., Idrissi, A., 2015. Brominated flame retardant trends in aquatic birds from the Salish Sea region of the west coast of North America, including a mini-review of recent trends in marine and estuarine birds. Sci. Total Environ. 502, 60-69.

Monteny, G.J., 2001. The EU Nitrates Directive: a European approach to combat water pollution from agriculture. Sci. World J. 1, 927-935.

Moreno, R., Jover, L., Diez, C., Sanpera, C., 2011. Seabird feathers as monitors of the levels and persistence of heavy metal pollution after the Prestige oil spill. Environ. Pollut. 159 (10), $2454 \mathrm{e} 2460$.

Mwangi, J.K., Lee, W.-J., Wang, L.-C., Sung, P.-J., Fang, L.-S., Lee, Y.-Y., ChangChien, G.-P., 2016. Persistent organic pollutants in the Antarctic coastal environment and their bioaccumulation in penguins. Environ. Pollut. 216, 924-934.

Nicholls, R.J., Cazenave, A., 2010. sea-level rise and its impact on coastal zones. Science 328 (5985), 1517-1520.

Nieto, J.M., Sarmiento, A.M., Olías, M., Canovas, C.R., Riba, I., Kalman, J., Delvalls, T.A., 2007. Acid mine drainage pollution in the tinto and odiel rivers (iberian pyrite belt, SW Spain) and bioavailability of the transported metals to the Huelva estuary. Environ. Int. 33 (4), 445-455.

Noto, A.E., Shurin, J.B., 2017. Early stages of sea-Level rise lead to decreased salt marsh plant diversity through stronger competition in mediterranean-climate marshes. PLoS One 12 (1).

Nyberg, E., Faxneld, S., Danielsson, S., Eriksson, U., Miller, A., Bignert, A., 2015. Temporal and spatial trends of PCBs, DDTs, HCHs, and HCB in Swedish marine biota 1969-2012. Ambio 44, S484-S497.

O'Higgins, T., Gilbert, A., 2014. Embedding ecosystem services into the marine strategy framework directive: illustrated by eutrophication in the north sea. Estuar. Coast Shelf Sci. 140, 146-152.

O'Donnell, J.P., Schalles, J.F., 2016. Examination of abiotic drivers and their influence on spartina alterniflora biomass over a twenty-eight year period using Landsat 5 TM satellite imagery of the Central Georgia Coast. Rem. Sens. 8 (6), 477. 
Osher, L., Leclerc, L., Wiersma, G., Hess, C., Guiseppe, V., 2006. Heavy metal contamination from historic mining in upland soil and estuarine sediments of Egypt Bay, Maine, USA. Estuar. Coast Shelf Sci. 70 (1), 169-179.

Paerl, H.W., Dennis, R.L., Whitall, D.R., 2002. Atmospheric deposition of nitrogen: implications for nutrient over-enrichment of coastal waters. Estuaries 25 (4), 677-693.

Popadic, A., Vidovic, J., Cosovic, V., Medakovic, D., Dolenec, M., Felja, I., 2013. Impact evaluation of the industrial activities in the Bay of Bakar (Adriatic Sea, Croatia): recent benthic foraminifera and heavy metals. Mar. Pollut. Bull. 76 (1), 333-348.

Pozo, K., Urrutia, R., Mariottini, M., Rudolph, A., Banguera, J., Pozo, K., Parra, O., Focardi, S., 2014. Levels of persistent organic pollutants (POPs) in sediments from Lenga estuary, central Chile. Mar. Pollut. Bull. 79 (1e2), 338-341.

Pruell, R.J., Taplin, B.K., Miller, K.M., 2017. Trends in nitrogen isotope ratios of juvenile winter flounder reflect changing nitrogen inputs to Rhode Island, USA estuarine systems. Mar. Pollut. Bull. 118 (1-2), 41-47.

Rabotyagov, S.S., Campbell, T.D., White, M., Arnold, J.G., Atwood, J., Norfleet, M.L., Kling, C.L., Gassman, P.W., Valcu, A., Richardson, J., 2014. Cost-effective targeting of conservation investments to reduce the northern Gulf of Mexico hypoxic zone. Proc. Natl. Acad. Sci. Unit. States Am. 111 (52), 18530-18535.

Ramesh, R., Chen, Z., Cummins, V., Day, J., D'Elia, C., Dennison, B., Forbes, D., Glaeser, B., Glaser, M., Glavovic, B., 2015. Landeocean interactions in the coastal zone: past, present \& future. Anthropocene 12, 85-98.

Regnier, P., Friedlingstein, P., Ciais, P., Mackenzie, F.T., Gruber, N., Janssens, I.A., Laruelle, G.G., Lauerwald, R., Luyssaert, S., Andersson, A.J., Arndt, S., Arnosti, C., Borges, A.V., Dale, A.W., Gallego-Sala, A., Godderis, Y., Goossens, N., Hartmann, J., Heinze, C., Ilyina, T., Joos, F., LaRowe, D.E., Leifeld, J., Meysman, F.J.R., Munhoven, G., Raymond, P.A., Spahni, R., Suntharalingam, P., Thullner, M., 2013. Anthropogenic perturbation of the carbon fluxes from land to ocean. Nat. Geosci. 6 (8), 597-607.

Rodellas, V., Garcia-Orellana, J., Masque, P., Feldman, M., Weinstein, Y., 2015. Submarine groundwater discharge as a major source of nutrients to the Mediterranean Sea. Proc. Natl. Acad. Sci. Unit. States Am. 112 (13), 3926-3930.

Satapathy, D., Panda, C., 2015. Spatio-temporal distribution of major and trace metals in estuarine sediments of Dhamra, Bay of Bengal, Indiadits environmental significance. Environ. Monit. Assess. 187 (1), 4133. 
Scavia, D., Field, J.C., Boesch, D.F., Buddemeier, R.W., Burkett, V., Cayan, D.R., Fogarty, M., Harwell, M.A., Howarth, R.W., Mason, C., Reed, D.J., Royer, T.C., Sallenger, A.H., Titus, J.G., 2002. Climate change impacts on US coastal and marine ecosystems. Estuaries 25 (2), 149-164.

Selman, M., Greenhalgh, S., Diaz, R., Sugg, Z., 2008. Eutrophication and hypoxia in coastal areas: a global assessment of the state of knowledge. World Resour. Inst. 284, 1-6.

Sericano, J.L., Wade, T.L., Sweet, S.T., Ramirez, J., Lauenstein, G.G., 2014. Temporal trends and spatial distribution of DDT in bivalves from the coastal marine environments of the continental United States, 1986-2009. Mar. Pollut. Bull. 81 (2), 303-316.

Shin, Y., Lee, E.J., Jeon, Y.J., Hur, J., Oh, N.H., 2016. Hydrological changes of DOM composition and biodegradability of rivers in temperate monsoon climates. J. Hydrol. 540, 538-548.

Sjafrie, N.D.M., Adrianto, L., Damar, A., Boer, M., 2017. Human appropriation of net primary production (HANPP) in seagrass ecosystem: an example from the east coast of Bintan Regency, Kepulauan Riau Province, Indonesia. Environ. Dev. Sustain. 1-17.

Smith, T.M., Reynolds, R.W., Peterson, T.C., Lawrimore, J., 2008. Improvements to NOAA's historical merged land-ocean surface temperature analysis (18802006). J. Clim. 21 (10), 22832296.

Sobrino-Figueroa, A.S., Caceres-Martinez, C., Botello, A.V., Nunez-Nogueira, G., 2007. Effect of cadmium, chromium, lead and metal mixtures on survival and growth of juveniles of the scallop Argopecten ventricosus (Sowerby II, 1842). J. Environ. Sci. Health Part A 42 (10), 1443-1447.

Song, Y., Yu, K., Zhao, J., Feng, Y., Shi, Q., Zhang, H., Ayoko, G.A., Frost, R.L., 2014. Past 140-year environmental record in the northern South China Sea: evidence from coral skeletal trace metal variations. Environ. Pollut. 185, 97-106.

Spencer, T., Schuerch, M., Nicholls, R.J., Hinkel, J., Lincke, D., Vafeidis, A.T., Reef, R., McFadden, L., Brown, S., 2016. Global coastal wetland change under sea-level rise and related stresses: the DIVA Wetland Change Model. Global Planet. Change 139, 15-30.

Statham, P.J., 2012. Nutrients in estuariesean overview and the potential impacts of climate change. Sci. Total Environ. 434 (18), 213-227.

Strickland, J.D.H., Parsons, T.R., 1972. A Practical Handbook of Seawater Analysis. Fisheries Research Board of Canada.

Strokal, M., Yang, H., Zhang, Y., Kroeze, C., Li, L., Luan, S., Wang, H., Yang, S., Zhang, Y., 2014. Increasing eutrophication in the coastal seas of China from 1970 to 2050. Mar. Pollut. Bull. 85 (1), 123-140. 
Su, C., Lu, Y., Johnson, A.C., Shi, Y., Zhang, M., Zhang, Y., Juergens, M.D., Jin, X., 2017. Which metal represents the greatest risk to freshwater ecosystem in Bohai Region of China? Ecosys. Health Sustain. 3 (2).

Sun, R.X., Luo, X.J., Tan, X.X., Tang, B., Li, Z.R., Mai, B.X., 2015. Legacy and emerging halogenated organic pollutants in marine organisms from the Pearl River Estuary, South China. Chemosphere 139, 565-571.

Szmant, A.M., 2002. Nutrient enrichment on coral reefs: is it a major cause of coral reef decline? Estuaries 25 (4), 743-766.

Taghon, G.L., Ramey, P.A., Fuller, C.M., Petrecca, R.F., Grassle, J.P., 2017. Benthic community structure and sediment properties in barnegat bay, New Jersey, before and after hurricane sandy. Estuar. Coast 40 (1), 160-172.

Taylor, S.M., 2009. Transformative ocean science through the VENUS and NEPTUNE Canada ocean observing systems. Nucl. Instrum. Methods Phys. Res. Sect. A Accel. Spectrom. Detect. Assoc. Equip. 602 (1), 63-67.

Thrush, S.F., Ellingsen, K.E., Davis, K., 2016. Implications of fisheries impacts to seabed biodiversity and ecosystem-based management. ICES J. Mar. Sci. 73 (S1), i44-i50.

Troost, T., De Kluijver, A., Los, F., 2014. Evaluation of eutrophication variables and thresholds in the Dutch North Sea in a historical contextda model analysis. J. Mar. Syst. 134, 45-56.

Ulen, B.M., Weyhenmeyer, G.A., 2007. Adapting regional eutrophication targets for surface watersdinfluence of the EU Water Framework Directive, national policy and climate change. Environ. Sci. Pol. 10 (7e8), 734-742.

Vane, C.H., Ma, Y.-J., Chen, S.-J., Mai, B.-X., 2010. Increasing polybrominated diphenyl ether (PBDE) contamination in sediment cores from the inner Clyde Estuary, UK. Environ. Geochem. Health 32 (1), 13-21.

Wang, P., Lu, Y., Wang, T., Zhu, Z., Li, Q., Zhang, Y., Fu, Y., Xiao, Y., Giesy, J.P., 2015. Transport of short-chain perfluoroalkyl acids from concentrated fluoropolymer facilities to the Daling River estuary, China. Environ. Sci. Pollut. Control Ser. 22 (13), 9626-9636.

Wang, T., Vestergren, R., Herzke, D., Yu, J., Cousins, I.T., 2016. Levels, isomer profiles, and estimated riverine mass discharges of perfluoroalkyl acids and fluorinated alternatives at the mouths of Chinese rivers. Environ. Sci. Technol. 50 (21), 11584-11592.

Wang, Y., Liu, D., Dong, Z., Di, B., Shen, X., 2012. Temporal and spatial distributions of nutrients under the influence of human activities in Sishili Bay, northern Yellow Sea of China. Mar. Pollut. Bull. 64 (12), $2708 \mathrm{e} 2719$. 
Ward, T.M., Grammer, G., Ivey, A., Carroll, J., Keane, J., Stewart, J., Litherland, L., 2015. Egg Distribution, Reproductive Parameters and Spawning Biomass of Blue Mackerel, Australian Sardine and Tailor off the East Coast during Late Winter and Early Spring, p. 86. Final Report, FRDC Project (2014-033).

Waycott, M., Duarte, C.M., Carruthers, T.J., Orth, R.J., Dennison, W.C., Olyarnik, S., Calladine, A., Fourqurean, J.W., Heck, K.L., Hughes, A.R., 2009. Accelerating loss of seagrasses across the globe threatens coastal ecosystems. Proc. Natl. Acad. Sci. Unit. States Am. 106 (30), 1237712381.

Webster, P.J., Holland, G.J., Curry, J.A., Chang, H.R., 2005. Changes in tropical cyclone number, duration, and intensity in a warming environment. Science 309 (5742), 1844-1846.

Wells, M.L., Trainer, V.L., Smayda, T.J., Karlson, B.S., Trick, C.G., Kudela, R.M., Ishikawa, A., Bernard, S., Wulff, A., Anderson, D.M., 2015. Harmful algal blooms and climate change: learning from the past and present to forecast the future. Harmful Algae 49, 68-93.

Wiltshire, K.H., Boersma, M., Carstens, K., Kraberg, A.C., Peters, S., Scharfe, M., 2015. Control of phytoplankton in a shelf sea: determination of the main drivers based on the Helgoland Roads Time Series. J. Sea Res. 105, 42-52.

Woodruff, J.D., Irish, J.L., Camargo, S.J., 2013. Coastal flooding by tropical cyclones and sea-level rise. Nature 504 (7478), 44-52.

Xing, J., Song, J., Yuan, H., Li, X., Li, N., Duan, L., Kang, X., Wang, Q., 2017. Fluxes, seasonal patterns and sources of various nutrient species (nitrogen, phosphorus and silicon) in atmospheric wet deposition and their ecological effects on Jiaozhou Bay, North China. Sci. Total Environ. 576, 617-627.

Xu, B., Yang, X., Gu, Z., Zhang, Y., Chen, Y., Lv, Y., 2009. The trend and extent of heavy metal accumulation over last one hundred years in the Liaodong Bay, China. Chemosphere 75 (4), 442-446.

Xu, X.G., Li, X., Chen, M.C., Li, X.Y., Duan, X.F., Zhu, G.R., Feng, Z., Ma, Z.G., 2016. Land-oceanhuman interactions in intensively developing coastal zone: demonstration of case studies. Ocean Coast Manag. 133, 280-36.

Yadav, K., Sarma, V., Rao, D., Kumar, M.D., 2016. Influence of atmospheric dry deposition of inorganic nutrients on phytoplankton biomass in the coastal Bay of Bengal. Mar. Chem. 187, 2534.

Yanezarancibia, A., Day, J.W., Reyes, E., 2015. Understanding the coastal ecosystem- based management approach in the Gulf of Mexico. J. Coast Res. 63 (63), 244-262. 
Yu, O.H., Lee, H.-G., Shim, W.J., Kim, M., Park, H.S., 2013. Initial impacts of the Hebei Spirit oil spill on the sandy beach macrobenthic community west coast of Korea. Mar. Pollut. Bull. 70 (1), $189 \mathrm{e} 196$.

Zhang, K., 2016. Regime shifts and resilience in China's coastal ecosystems. Ambio 45 (1), 89 e98.

Zhang, Y., Yu, J., Jiang, Z., Wang, Q., Wang, H., 2015. Variations of summer phytoplankton community related to environmental factors in a macro-tidal estuarine embayment, Hangzhou Bay, China. J. Ocean Univ. China 14 (6), 1025-1033.

Zhou, M., Klaus, B.-B., Vereecken, Harry, Bruggemann, Nicolas, 2017. A meta-analysis of soil salinization effects on nitrogen pools, cycles and fluxes in coastal ecosystems. Global Change Biol. 23 (3), 1338-1352.

Zhu, Z., Wang, T., Meng, J., Wang, P., Li, Q., Lu, Y., 2015. Perfluoroalkyl substances in the Daling River with concentrated fluorine industries in China: seasonal variation, mass flow, and risk assessment. Environ. Sci. Pollut. Control Ser. 22 (13), 10009-10018. 